\title{
Assessing PIIGS Country Performance against Themselves and the EU
}

\author{
Samuel D. Barrows ${ }^{1}$ \\ ${ }^{1}$ College of Social Sciences, KIMEP University, Almaty, Kazakhstan \\ Correspondence: Samuel D. Barrows. E-mail: sam_barrows@yahoo.com
}

Received: December 14, 2019

Accepted: February 21, $2020 \quad$ Online Published: March 30, 2020

doi:10.5539/ass.v16n4p74

URL: https://doi.org/10.5539/ass.v16n4p74

\begin{abstract}
This study reviews research and provides discussions on various aspects of optimal currency areas, the link between debt and growth rates, and government debt levels for the PIIGS countries which consist of Portugal, Ireland, Italy, Greece, and Spain. Ten years after the Great Financial Crisis (GFC), and five years after 2013, the year of peak debt levels to GDP for the PIIGS countries and the year of the lowest real GDP levels between 2011 and 2018 for the PIIGS countries, this study provides an assessment of PIIGS country performance relative to each other and to the EU. The study time frame includes the years 2013 and 2018 using twelve measurements grouped into four sections which provide insight into the economic performance of the PIIGS countries. The sections are Trade Flows, Industry / Debt / Foreign Direct Investment (FDI), Demographics, and Economic Outcomes. Based on a summary analysis of the measurements, the overall ranking is: Ireland, followed by the EU, Spain, Portugal, Italy then Greece.
\end{abstract}

Keywords: PIIGS, Debt Crisis, Optimal Currency Area, Portugal, Ireland, Italy, Greece, Spain

\section{Introduction}

The European Union (EU) was created in 1957 for the implementation of the free movement of goods, services, labor, and capital which established a formal economic relationship for the EU members (EUR-Lex, 2019). The EU was initially structured as an economic arrangement. Given the history of wars on the continent, the belief was that if the countries were economically connected, it would be in their own best interest to avoid conflicts which could adversely impact this economic relationship (Martin \& Waller, 2012). With regard to the reduction of armed conflicts as well as the development of a single market on the continent, the EU implementation is deemed by most to have been a success, at least when based upon these criteria.

In 1992, the Economic and Monetary Union (EMU) was created paving the way for the introduction of a currency to be administered by the European Central Bank (ECB) with the launch of the euro on 1 January 1999 (EUR-Lex, 2019). The thinking by many then and now is that if properly implemented, the euro has various worthwhile benefits for all members. The use of a single currency eliminates exchange rate risks, "prevents protectionist policies", and provides the potential for a low inflation environment (Pureza \& Mortagua, 2016).

Once accepted as part of the euro area, EMU member countries are mandated to adhere to certain principles. With regard to budgets and debt, under the Stability and Growth Pact, "member states are required to limit the general government deficit to at most 3\% of GDP and public debt to at most $60 \%$ of GDP (or to ensure that it sufficiently decreases towards 60\%)" (EC Europa, 2019). The mandate of the ECB and EMU member central banks is price stability which is comprised of targeting inflation at under $2 \%$ while providing an environment for balanced economic growth with full employment, by managing bank reserves, interest rates, and money supply (Banca Italia, 2019).

\section{Literature Review}

\subsection{Optimal Currency Area}

With the creation of the EU in 1957, the currency issue would be one that would need to be addressed for the trading block. Research in 1961 led to the concept of an Optimal Currency Area (OCA) where members of the OCA could coordinate business cycles and policies in order to minimize external shocks, as long as the number of members did not grow too large to manage (Mundell, 1961). An oversized OCA discounts issues around the smaller players since they have less to contribute economically (Saunders, 2011). If an OCA grows too large, its marginal benefits move below its marginal costs for some of its members (Maloney \& Macmillen, 1999). 
The OCA theory hypothesizes that an OCA has become too large if it cannot maintain balances in labor and export markets and should reduce its size until the members achieve harmony in their economic spheres (Saunders, 2011). In an OCA, the single currency reduces tools which would normally be utilized by "the less developed countries" (Artner \& Rona, 2012). If an OCA is too large, there are "sub-regions with conflicting monetary and fiscal needs", with a solution to separate the OCA into multiple sub-regions, each with its own currency (Saunders, 2011). This would provide for a further targeted approach that would more precisely benefit the members of these sub-regions. Member countries on the periphery of an OCA, like the PIIGS countries, which consist of Portugal, Ireland, Italy, Greece, and Spain, within the EU, could be thought of as a sub-region within an OCA. The PIIGS countries see different dynamics from most of the other EU members and would see benefit in using a different currency that can be adjusted based on their own economic circumstances (Saunders, 2011).

Countries that cannot maintain adequate fiscal policies, monetary policies, or regulatory certainty will have difficulty attracting investment and will not be competitive in the global marketplace (Pureza \& Mortagua, 2016). A study in 1969 warned of major issues for smaller countries in the EU if monetary policy was implemented primarily for the advancement of the major economies (Kenen, 1969). Countries with significant trade on the global stage were advantaged by the euro, in addition, these countries also wielded the most influence on monetary policy implementation (Artner \& Rona, 2012). To realize improved overall performance, "there must be common business cycles within an OCA, so that shocks are not unevenly distributed" (Kenen, 1969). Within the euro area, bifurcation has occurred in the EU economies, as "the more advanced gained further competitiveness and the less developed lost competitiveness" (Artner \& Rona, 2012).

There is an inherent, "built-in bias" that separates the EU into two groups: the more developed countries with more fiscal prudence and the less developed countries with less fiscal restraints in place (Artner \& Rona, 2012). The euro has created weakness on the periphery while consolidating power in the center of the continent, primarily in Germany and France (Pureza \& Mortagua, 2016). Countries on the periphery, such as the PIIGS countries, could benefit from leaving the euro since they could then devalue their currency if necessary "to become competitive again" (Dammann, 2012). Creating another currency region within the EU for countries with fiscally challenged governments, such as the PIIGS countries, is a mechanism that may be attractive for some countries (Blueschke \& Neck, 2011). One alternative to this would be for Germany to leave the euro area, which would permit Germany to reduce its liabilities to other EU members and allow the remaining euro countries to establish monetary policies that would benefit the smaller players (Dammann, 2012). This solution has at least one drawback. Currently, a country leaving the euro area would almost certainly be forced to leave the EU and the single market, at least this is the view many have on the subject (Dammann, 2012).

The OCA theory infers that everyone benefits if fiscal balances are maintained while labor is free to move under a common currency as a means to achieve macroeconomic equilibrium (Saunders, 2011). Worker mobility in the $\mathrm{EU}$ is a function of the tax regimes in the various member countries and provides workers with the ability to move to other locations in search of better opportunities (Liapis et al., 2013). However, at least one study noted that labor mobility is restricted by the continued use of non-tariff barriers and subsidies (Silvia, 2004). EU countries on the geographic fringes, like the PIIGS countries, lost competitiveness due to the relative currency strength of the euro (Artner \& Rona, 2012). Higher wage growth in the PIIGS countries led to less competitive environments in those countries (Pureza \& Mortagua, 2016). If workers in the PIIGS countries cannot find work in their home countries, and the currency cannot be devalued to increase competitiveness, workers may attempt to seek better opportunities in other EU countries (Saunders, 2011). That is, assuming that the workers are qualified for those opportunities.

\subsection{PIIGS Debt}

Prior to joining the EMU, debt financing for a country was assessed on that country's market risks. After joining the EMU, countries predisposed to higher inflation now had access to cheaper financing than prior to their joining the euro area (Artner \& Rona, 2012). The interest rates for such countries on their long-term "debt converged to the rate paid by Germany and France" as financial markets adopted the view that the euro area member risks were similar even though fiscal realities were much different (Martin \& Waller, 2012). Easy money based on Germany's need as the largest economy in the EU led to the formation of bubbles for countries on the geographic and economic fringes (Bibow, 2012). Even if "banks run out of collateral, they can still obtain liquidity through the Emergency Liquidity Assistance (ELA)" facilities (EC Europa, 2019). The utilization of the ELA was used by the PIIGS countries, most notably Greece and Ireland, and this new method provided central banks the ability to create money through commercial banks in situations when previously the ECB would have been expected to reject the collateral used in these transactions (Merler \& Pisani-Ferry, 2012). 
From 2004 through 2007, EU bond spreads between the various countries were narrowed below previous norms (Henning \& Kessler, 2012). This cheap money made "bad structural policies more financeable" and the PIIGS countries experienced financial booms which pushed debt usage to unsustainable levels and contributed to decreased competitiveness which reduced growth rates (Balcerowicz, 2014). Increased real estate investment in Spain and Ireland, increased deficits in Greece, and "increased internal demand" in Portugal, led to a real exchange rate appreciation which pushed local wages above productivity levels which reduced competitiveness leading to a decrease of exports and an increase of imports (Pureza \& Mortagua, 2016). Meanwhile, Italy was in an "unsustainable" situation due to the accumulation of debt (Brady \& Magazzino, 2018). As a result, the bond yields for the PIIGS countries skyrocketed above that from the core euro area members (Kinsella, 2012). The resultant outcome is that "markets no longer consider sovereign debt low-risk" (Cecchetti et al., 2010).

After the Great Financial Crisis (GFC), growing "debts due to expansionary fiscal policies enacted during the crisis to reduce the loss in output and employment" placed countries with these high debt loads at a disadvantage compared to those countries with lower debt levels (Blueschke \& Neck, 2011). The increases of government debt in the PIIGS countries after the GFC had a negative impact on market confidence (Teica, 2012). The PIIGS countries suffered from both high unemployment and high debt along with reduced exports which further complicated matters (Saunders, 2011). It could be said "that the euro has been the catalyst and the amplifier of the deteriorating competitiveness of the PIIGS" countries (Artner \& Rona, 2012). In the end, "treating all sovereign debt equally, the ECB sent markets the wrong signal" (Gil \& de Souza, 2013).

The debt crisis related to the PIIGS countries began in 2010 with the realization that the Greek budget deficit exceeded $12 \%$ of its GDP, more than four times the EU prescribed budget limit of $3 \%$ with the ECB refusing to accept Greek "bonds as collateral for loans from private banks" (Bellalah et al., 2016). Greece received bailout packages in 2010 and 2011; Ireland received its bailout in 2010; Portugal received its bailout in 2011 then also in 2011, Italy and Spain received assistance with the ECB buying their bonds to push down their borrowing costs (Liu \& Wang, 2013). The economic slowdown in the PIIGS countries led to recessions for five of the countries in 2009, two in 2010, three in 2011, and four in 2012 and 2013 (World Bank, 2019).

The inability to enforce fiscal restraints on euro area members which were established in EU treaties meant that spending in the PIIGS countries outpaced budget revenues in an unsustainable manner (Brady \& Magazzino, 2018). ECB policies "encouraged banks in the problem countries to buy the bonds of their national government" (Balcerowicz, 2014). With the ECB buying member debt as opposed to implementing policies that coordinated the entire EU zone resulted in a divergence of outcomes which grew more divergent with time (Saunders, 2011). The bailout of the banks is one significant cause of the increased debt levels in the PIIGS countries (Artner \& Rona, 2012). Bailouts and crisis lending can lead to moral hazard, where participants increasingly use risk because of safety nets: "the ECB's easy monetary policy, international and domestic regulations that encouraged risky behavior of lenders and borrowers in the financial markets, and neglect of the agreed fiscal constraints by eurozone governments" (Balcerowicz, 2014).

\subsection{Debt and Economic Growth}

Fiscal restraints in the EU have been a concern since its inception. One study evaluated the fiscal solvency status of eight EU countries from 1970 to 1994 and found that only France and Germany conformed to the measured guidelines (Vanhorebeek \& van Rompuy, 1995). There is an implied future cost of high levels of debt. One study opined on the PIIGS countries specifically stating "a high public debt burden implies higher future taxes (inflation is also a tax) or lower future government spending, if the government is expected to repay its debts" (Reinhart \& Rogoff, 2010). One question is whether to reduce spending or raise taxes to increase economic growth. A study of 18 EMU countries from 1980 to 2015 found that reducing taxes and increasing spending generates economic growth, but reducing spending generates higher growth rates than increasing taxes (Magazzino \& Lepore, 2015). Another study also assessed fiscal policies of the same 18 EMU countries from 1980 to 2015 and confirmed that reducing "expenditures rather than increasing taxes, are more likely to boost economic growth" then further added that reducing investment spending, on its own, could lead to a slowing of economic expansions (Forte \& Magazzino, 2016).

The implementation of EU policies, or more precisely the lack of implementation of some of the EU policies, resulted in below market interest rates and the increased use of debt. The outcome: "low interest rates and relatively higher inflation led to" annual deficits and higher debt to GDP readings (Pureza \& Mortagua, 2016). Fiscal constraints may be a necessary evil, but they provide for more certainty regarding a realistic chance for debt repayment (Balcerowicz, 2014). The common assumption for utilizing debt is the assumption that governments will raise taxes at some point in the future to repay the debt and if investors have high confidence 
of this repayment, subsequent issuances of the country's debt instruments would be less of a concern (Martin \& Waller, 2012). However, increased debt levels can lead to austerity measures which can have adverse impacts during times of contraction or recession (Kurecic et al., 2018). The alternative is to have the economy grow faster than the debt grows. EU countries with these high debt levels would need annual growth to exceed $4 \%$ and last well over a decade to remedy the increased debt levels (Artner \& Rona, 2012). Increased trade can also provide for fiscal improvement. Countries in a debt crisis can navigate better if they can maintain a trade surplus that brings foreign currency to the domestic economy (Saunders, 2011).

There is some consensus in that some levels of debt can be helpful. A well-referred study of 44 countries covering 200 years quantified the threshold for debt impacts on GDP. The study found that for government debt less than $90 \%$ of GDP, there is a weak linkage between debt and economic growth, whereas when debt is greater than " $90 \%$, median growth rates fall by $1 \%$, and average growth falls considerably more" (Reinhart \& Rogoff, 2010). Another study of twelve Organization for Economic Cooperation and Development (OECD) countries scrutinized this concept further. It summarized, "the risk that persistently high levels of public debt will drive down capital accumulation, productivity growth and long-term potential growth" (Cecchetti et al., 2010). However, not all agree with this concept. A study of advanced countries between 1946 and 2009 concluded that the growth rates between countries with debt exceeding $90 \%$ of GDP and those with less debt have no material difference in growth rates (Herndon et al., 2013).

For more clarification, further studies have been conducted which provide additional understanding on the debt to economic growth relationship. One such study which included 36 countries, 25 from the EU and 11 from the OECD, separated into two groups: a developed group, and an emerging group (Mencinger et al., 2015). The results show a dichotomy of debt impacts in that at low debt levels there is a positive impact on growth, and with higher levels of debt this impact turns negative above a certain threshold. The developed group referenced data from 1980 to 2010 and the emerging group referenced data from 1995 to 2010; the study found that the threshold level for the developed group is approximately $90 \%$ whereas the threshold level for the emerging group is approximately 45\% (Mencinger et al., 2015). Additionally, a study which included both developing and developed economies from 1960 to 2012 consisting of 118 countries confirm the link between higher debt levels and long-term negative impacts on economic performance (Eberhardt \& Presbitero, 2015).

There is some debate as to the impacts that increased government debt can have on the macroeconomic environment. Not all studies agree with the premise that increased debt levels reduce macroeconomic growth. One study comprised of forty developing and developed economies between 1965 and 2010 found no consistent link between debt levels and their impact on economic growth (Chudik et al., 2015). Another study of 17 OECD countries from 1980 to 2005 found "no evidence that debt has a causal effect on economic growth" (Panizza \& Presbitero, 2014). A study of 23 OECD members between 1996 and 2007 found no negative measureable impacts of increased public debt on economic growth that was statistically significant (Dar \& Amirkhalkhali, 2014). Additionally, a study found somewhat similar results in that for the more developed economies, increased public debt has less impacts overall or the impacts are simply more neutral (Ahlborn \& Schweickert, 2015).

There are other impacts related to increased debt levels with one study citing the possibility of reduced private investments due to the high levels of government debt, most notably in emerging markets (Fincke \& Greiner, 2015). This dynamic is known as "crowding-out" and can reduce the amount going toward private investments plus can raise the cost of those investments through higher interest rates (Parkin, 2012). Further confirmation of this comes from a study which found that increased public debt levels impact the savings and investment climate and reduces productivity in a twelve-country assessment in the EU (Checherita-Westphal \& Rother, 2012).

\section{Methodology}

The focus of this study is to compare the various measurements of the PIIGS countries along with the EU then examine their performance relative to each other. This is done by assessing the countries using twelve measurements grouped into four sections which provide insight into the economic performance of the countries. These sections are Trade Flows, Industry / Debt / FDI, Demographics, and Economic Outcomes. The measurements selected are based on a previous study which evaluated the impacts of the NAFTA agreement on the signatory countries using eleven comparable measurements (Barrows, 2019).

The twelve measurements used in this study are comprised of Trade ( $\%$ of GDP); Exports of goods and services ( $\%$ of GDP); External trade balance ( $\%$ of GDP); Industry (including construction), value added ( $\%$ of GDP); General government debt (\% of GDP); FDI net inflows (\% of GDP); Population growth (annual \%); Age dependency ratio, old ( $\%$ of workers), least ranked (this is the ratio of older dependents, people older than 64 , to the working-age population, those ages 15-64); Unemployment, total (\% of total labor force); Inflation, GDP 
deflator (annual \%); Current account balance (\% of GDP); and GDP per capita (current USD).

The data utilized in this study is provided by the World Bank databank facility except for the General government debt measurement which is provided by Eurostat (World Bank 2019; Eurostat, 2019). The databank facility provides quantitative data for a myriad of measurements, some going back to 1960. The World Development Indicators database is selected with annual readings being utilized. The data for measurements selected is provided by the World Bank; Eurostat; International Monetary Fund; International Financial Statistics; the OECD; the United Nations; and various national statistics offices; (World Bank, 2019).

The study time frame includes the years 2013 and 2018. The year 2013 is selected for reference as it is the year of peak debt levels to GDP for the PIIGS countries plus the year of the lowest real GDP levels, between 2011 and 2018, for the PIIGS countries (Eurostat, 2019; World Bank, 2019). It is also generally viewed as the low point for the PIIGS economies as a group. The year 2018 is selected for reference as it is the most recent year that data is available and provides a comparative basis five years from the 2013 economic low point. It is also the year with the highest average real GDP levels for the group.

\section{Results}

The data included in the study is listed in the Appendix. Table 1 provides the 2013 and 2018 measurements plus trends for Portugal, Ireland, and Italy. Table 2 provides the 2013 and 2018 measurements plus trends for Greece, Spain, and the EU. Table 3 provides the 2018 measurements for the five PIIGS countries and the EU. Table 4 provides the 2018 rankings for the five PIIGS countries and the EU.

The results are discussed below with a focus on the 2018 measurements along with a comparison back to 2013 to show trends. The discussions focus on the top performers and the bottom performers along with a reference to the EU reading for each measurement. For a more detailed look at all measurements, the various tables can be accessed in the Appendix.

\subsection{Trade Flows}

The first section is Trade Flows and includes the following: Trade (\% of GDP); Exports of goods and services (\% of GDP); and External trade balance (\% of GDP). Trade (\% of GDP) is the sum of exports and imports each year as a percentage of GDP (World Bank, 2019). With regard to trade, the top performer in 2018 is Ireland with a reading of 209.81, an increase of $11 \%$ from 2013. The bottom performer in 2018 is Italy with a reading of 61.01 , an increase of $10 \%$ from 2013. For reference, the EU reading is 86.49 , an increase of $6 \%$ from 2013 . With regard to exports, the top performer in 2018 is Ireland with a reading of 120.52, an increase of $16 \%$ from 2013 . The bottom performer in 2018 is Italy with a reading of 31.76, an increase of $10 \%$ from 2013. For reference, the EU reading is 44.74 , an increase of $6 \%$ from 2013 . With regard to external trade balances, the top performer in 2018 is Ireland with a reading of 31.23, an increase of $66 \%$ from 2013. The bottom performer in 2018 is Greece with a reading of -0.26 , an increase of $91 \%$ from 2013 . For reference, the EU reading is 2.99 , an increase of $12 \%$ from 2013.

\subsection{Industry / Debt / FDI}

The second section is Industry / Debt / FDI and includes the following: Industry (including construction), value added ( $\%$ of GDP); General government debt ( $\%$ of GDP); and FDI net inflows (\% of GDP). The industry measurement includes value added in the following sectors: mining, manufacturing, construction, electricity, water, and gas (World Bank, 2019). With regard to industry, the top performer in 2018 is Ireland with a reading of 35.42, an increase of $46 \%$ from 2013. The bottom performer in 2018 is Greece with a reading of 15.27, an increase of $4 \%$ from 2013. For reference, the EU reading is 21.87 , a decrease of less than $1 \%$ from 2013 . With regard to debt levels, the top performer with the least proportional measurement in 2018 is Ireland with a reading of 64.80, a decrease of $46 \%$ from 2013. The bottom performer in 2018 is Greece with a reading of 181.10, an increase of $2 \%$ from 2013. For reference, the EU reading is 80.00 , a decrease of $7 \%$ from 2013 . With regard to FDI inflows, the top performer in 2018 is Ireland with a reading of 5.68, a decrease of $73 \%$ from 2013 . The bottom performer in 2018 is Italy with a reading of 1.49, an increase of $63 \%$ from 2013 . For reference, the EU reading is 0.49 , a decrease of $86 \%$ from 2013 .

\subsection{Demographics}

The third section is Demographics and includes the following: Population growth (annual \%); Age dependency ratio, old ( $\%$ of working-age population); and Unemployment, total (\% of total labor force). With regard to population growth, the top performer in 2018 is Ireland with a reading of 0.95 , an increase of $81 \%$ from 2013 . The bottom performer in 2018 is Greece with a reading of -0.25 , an increase of $65 \%$ from 2013. For reference, the EU reading is 0.20 , a decrease of $33 \%$ from 2013. With regard to the ratio of older dependents (people older 
than 64) to the working-age population (those ages 15-64), the top performer with the least proportional measurement in 2018 is Ireland with a reading of 22.24, an increase of $19 \%$. The bottom performer with the largest proportional measurement in 2018 is Italy with a reading of 36.86 , an increase of $10 \%$. For reference, the EU reading is 31.09 , an increase of $11 \%$ from 2013 . With regard to the unemployment rate, the top performer with the least proportional measurement in 2018 is Ireland with a reading of 5.69, a decrease of 59\% from 2013. The bottom performer in 2018 is Greece with a reading of 19.21, a decrease of 30\% from 2013. For reference, the EU reading is 6.82 , a decrease of $37 \%$ from 2013.

\subsection{Economic Outcomes}

The fourth section is Economic Outcomes and includes the following: Inflation, GDP deflator (annual \%); Current account balance (\% of GDP); and GDP per capita (current USD). With regard to the highest inflation rate, the top performer in 2018 is Ireland with a reading of 1.52, an increase of 14\% from 2013. The bottom performer in 2018 is Greece with a reading of 0.55 , an increase of $123 \%$ from 2013. For reference, the EU reading is 1.92 , an increase of $47 \%$ from 2013 . With regard to current account balances, the top performer in 2018 is Ireland with a reading of 9.21 , an increase of $52 \%$ from 2013. The bottom performer in 2018 is Greece with a reading of -2.92 , a decrease of $42 \%$ from 2013. For reference, the EU reading is 0.00 , with no change from 2013. With regard to GDP per capita, the top performer in 2018 is Ireland with a reading of 78,806 USD, an increase of $53 \%$ from 2013. The bottom performer in 2018 is Greece with a reading of 20,324 USD, a decrease of 7\% from 2013. For reference, the EU reading is 36,546 USD, an increase of 3\% from 2013.

\subsection{Section and Overall Rankings}

The top performer in the Trade Flows section is Ireland and the bottom performer is Italy. The top performer in the Industry / Debt / FDI section is Ireland and the bottom performer is Greece. The top performer in the Demographics section is Ireland and the bottom performer is Greece. The top performer in the Economic Outcomes section is Ireland and the bottom performer is Greece. Based on a summary analysis of the measurements, the overall ranking is: Ireland, followed by the EU, Spain, Portugal, Italy then Greece.

\section{Discussion}

The study time frame saw anemic GDP per capita growth of 3\% in the EU from 2013 to 2018, while Greece and Italy saw negative growth rates at $-7 \%$ and $-3 \%$, respectively. Ireland was the only PIIGS country that saw double digit growth, at $53 \%$, during the same time period. The difference in the Ireland performance was not random. Ireland's Industrial Development Authority (IDA), a state body focused on attracting FDI to Ireland, increasingly targeted high-tech companies from the US, and based on the success of these efforts, cluster effects were realized where numerous other companies installed their EU headquarters in Ireland which further increased FDI, employment, and exports (Brazys \& Regan, 2015).

These cluster effects are the result of advantages other companies see in infrastructure, regulations, work practices, and potential employees that make it more likely that those companies will relocate to Ireland as well. Low tax rates are also a draw. Ireland's statutory corporate tax rate of $12.5 \%$ is less than half the average of the other PIIGS countries, with Portugal at 30\%; Italy at 24\%; Greece at 28\%; and Spain at 25\% (OECD Tax, 2019). An educated workforce is also an advantage for Ireland. Within the PIIGS countries, Ireland has the highest proportion of 25-34 year olds with tertiary education at $56.2 \%$ with Portugal at $35.1 \%$; Italy at $27.7 \%$; Greece at 42.8\%; and Spain at 44.3\% (OECD Edu, 2019). Other benefits for Ireland include the use of the English language and a location that is adjacent to the United Kingdom, in addition to being geographically and culturally closer to the United States than the other PIIGS countries. Ireland's 2018 GDP at 382 billion USD represents only $2 \%$ of the EU 2018 GDP reading of 18,756 billion USD (World Bank, 2019).

With regard to the bottom two performers, Italy and Greece, both were ranked in the lower half of the six participants in both Trade to GDP and Export to GDP measurements. Italy had a positive balance of trade, while Greece had a negative balance of trade. Greece had the lowest reading of Industry to GDP and the highest level of debt to GDP. Greece was the first country "to suffer from the crisis of sovereign debt following the lowering of its sovereign credit rating" (Bellalah et al., 2016). Both Italy and Greece were at the bottom of the FDI readings. This is an important reading in that wary investors may not invest in countries with substantial fiscal woes. Most critically, "FDI is seen as beneficial for economic growth" (Barrows, 2018). Low FDI levels will make it more difficult to turn things around.

Both Italy and Greece saw negative population growth while Italy had the highest proportion of people over 64 years of age in relation to the working age population with Greece not far behind. These two measurements point to a shrinking population with the potential of increased health care costs related to growing elderly populations. 
One study opined that as serious an issue public debt is if it exceeds " $100 \%$ of GDP, an even greater danger arises from a rapidly ageing population" (Cecchetti et al., 2010). While the unemployment rates in both countries were in the worst half of the study participants, Greece's reading of $19.21 \%$ unemployment is a certain concern. Since "Greece cannot increase exports by currency devaluation, its labor must find somewhere else to go" (Saunders, 2011). With regard to growing elderly populations and increased global competition, support for retirees and low-skilled workers are increasing concerns in Europe (Tanner, 2013). This is especially true in both Italy and Greece. Both countries also saw weak levels of inflation under $1 \%$ during the study time frame while Greece had the worst reading on its current account balance and had the lowest GDP per capita in the study. Italy's 2018 GDP at 2,074 billion USD is 9.5 times larger than Greece's 2018 GDP at 218 billion USD (World Bank, 2019).

With regard to the two middle performers, Spain and Portugal, the Iberian Peninsula countries entered the crisis in different ways. A real estate boom in Spain and "increased internal demand" in Portugal were among the root causes for the two countries (Pureza \& Mortagua, 2016). Portugal also had issues on the regulatory front and recurring fiscal problems (Balcerowicz, 2014). As a result of measures enacted, the two economies saw mixed results. Portugal was second in Trade to GDP and was third in Exports to GDP while Spain was fifth in both readings. Both countries had a positive balance of trade. Spain was second in both Industry to GDP and FDI while Portugal's debt to GDP of $121.50 \%$ is still a concern. Spain was second in both population growth and was second in the least proportion of older citizens while Portugal was fifth in both measurements. In the recent past, both Spain and Portugal added labor flexibility through the implementation of regulatory reforms (Balcerowicz et al., 2013). These measures had varying results as Portugal had the second lowest unemployment rate while Spain had the second highest, behind only Greece.

Inflation in Spain and Portugal was subdued, higher than Italy and Greece, but lower than Ireland and the EU. Spain had a positive current account balance while Portugal had a negative current account balance. The GDP per capita grew for both Spain and Portugal, at $4 \%$ and $7 \%$, respectively, however, Portugal's reading is the second lowest, behind only Greece. Spain and Portugal are geographically isolated from the rest of Europe. Spain is Portugal's biggest trading partner while Portugal is Spain's third largest trading partner, behind France and Germany (OEC World, 2019). Spain's 2018 GDP at 1,426 billion USD is 6 times larger than Portugal's 2018 GDP at 238 billion USD (World Bank, 2019).

\section{Conclusion}

The intent of this study is to assess the PIIGS country performances against themselves and the EU. The creation of the EU led to an implementation of an OCA which became sub-optimal for some of its members, specifically for the PIIGS countries. As a result of this dynamic, debt levels ballooned because of cheap money. Later, when PIIGS country debt was priced more correctly, the cost of debt became unmanageable.

Financial recovery for the PIIGS countries has been at three speeds with Italy and Greece having negative growth between 2013 and 2018, Spain and Portugal with marginal single-digit growth during the same time frame while Ireland jumped ahead with $53 \%$ growth. The EU also saw weak growth, worse than Spain and Portugal, but better than Italy and Greece. The 2018 debt levels for four out of the five PIIGS countries were similar to that in 2013 , with only Ireland changing substantially with a $46 \%$ reduction. The unemployment rate for the PIIGS countries improved at an average of $41 \%$ during the study time frame, while the EU saw a $37 \%$ improvement.

There are no current plans to introduce another currency for a sub-region in the OCA known as the EU. Even without this, seeking additional input from countries on the EU periphery may result in a more balanced implementation of monetary policy and it is hoped that more benefits would accrue to the smaller economies which would make the OCA perform better for more countries as opposed to those only in the core area.

\section{Acknowledgements}

This research did not receive any specific grant from funding agencies in the public, commercial, or not-for-profit sectors. There are no conflicts of interest.

\section{References}

Ahlborn, M., \& Schweickert, R. (2016). Public Debt and Economic Growth - Economic Systems Matter. Centre for European Governance and Economic Development Research Discussion Paper Number 281. https://doi.org/10.2139/ssrn.2740988

Artner, A., \& Rona, P. (2012). Euros(c)eptic - the Theory of the Optimum Currency Area and the Practice of the Euro. Romanian Journal of European Affairs, 12(2), 80+. Retrieved November 15, 2019, from 
https://www.academia.edu/5334901/A._Artner_-_P._R\%C3\%B3na_Euros_c_eptic_-_The_Theory_of_the Optimum_Currency_Area_and_the_Practice_of_the_Euro

Balcerowicz, L., Rzonca, A., Laszek, A., \& Kalina, L. (2013). Economic Growth in the European Union. Brussels: Lisbon Council (e-book). Retrieved November 1, 2019, from https://docplayer.net/4163387Economic-growth-in-the-european-union-16-x-2013-leszek-balcerowicz-lech-kalina-aleksander-laszek-andr zej-rzonca.html

Balcerowicz, L. (2014). Euro Imbalances and Adjustment: A Comparative Analysis. The Cato Journal, 34(3), 453. Retrieved November 15, 2019, from https://pdfs.semanticscholar.org/38ef/dc7adala0bd59ae8f50c6c42 1f5993dc86fe.pdf

Banca Italia. (2019). Retrieved November 22, 2019, from https://www.bancaditalia.it/compiti/polmon-garanzie/ index.html?com.dotmarketing.htmlpage.language $=1$

Barrows, S. (2018). Do Sub-Saharan Countries in Africa Have the Dutch Disease? Asian Social Science, 14(5), 14-28. https://doi.org/10.5539/ass.v14n5p14

Barrows, S. (2019). NAFTA Country Impacts: 25 Years After Implementation. Asian Social Science, 15(6), 7-18. https://doi.org/10.5539/ass.v15n6p7

Bellalah, Ma., Bellalah, Mo., \& Boussada, H. (2016). Modeling Transmissions of Volatility Shocks: Application to CDS Spreads during the Euro Area Sovereign Crisis. International Journal of Business, $21(1), 1$. $\begin{array}{llll}\text { Retrieved } & \text { November } & 20, & 2019,\end{array}$ https://www.craig.csufresno.edu/ijb/Volumes/Volume\%2021/V211-1.pdf

Bibow, J. (2012). The Euro Debt Crisis and Germany's Euro Trilemma. Levy Economics Institute working paper 721. The Levy Economics Institute of Bard College. Annandale-on-Hudson, New York. Retrieved November 20, 2019, from https:/www.econstor.eu/bitstream/10419/79483/1/715661795.pdf

Blueschke, D., \& Neck, R. (2011). Core and Periphery in a Monetary Union: A Macroeconomic Policy Game. International Advances in Economic Research, 17(3), 334. https://doi.org/10.1007/s11294-011-9303-6

Brady, G. L., \& Magazzino, C. (2018). Fiscal Sustainability in the EU. Atlantic Economic Journal, $46(3), 297$. https://doi.org/10.1007/s11293-018-9588-4

Brazys S., \& Regan, A. (2015). These Little PIIGS Went to Market: Enterprise Policy and Divergent Recovery in European Periphery. UCD Geary Institute for Public Policy Discussion Paper Series: WP2015/17. Retrieved November 16, 2019, from http://hdl.handle.net/10197/7413

Cecchetti, S. G., Mohanty, M. S., \& Zampolli, F. (2010). The Future of Public Debt: Prospects and Implications. Bank for International Settlements Working Paper No. 300. https://doi.org/10.2139/ssrn.1599421

Checherita-Westphal, C., \& Rother, P. (2012). The Impact of High Government Debt on Economic Growth and its Channels: An Empirical Investigation for the Euro Area. European Economic Review, 56, 1392-1405. https://doi.org/10.1016/j.euroecorev.2012.06.007

Chudik, A., Mohaddes, K., Pesaran, M. H., \& Raissi, M. (2015). Is there a debt-threshold effect on output growth? The Review of Economics and Statistics, 99(1), 135-150. https://doi.org/10.1162/REST_a_00593

Dammann, J. (2012). The Right to Leave the Eurozone. Texas International Law Journal, 48(2). Retrieved November 25, 2019, from https://ssrn.com/abstract=2262873

Dar, A. A., \& Amirkhalkhali, S. (2014). On the Impact of Public Debt on Economic Growth. Applied Econometrics and International Development, 14(1), 21-32. Retrieved November 5, 2019, from https://www.researchgate.net/publication/282916278_On_the_impact_of_public_debt_on_economic_growt $\mathrm{h}$

Eberhardt, M., \& Presbitero, A. F. (2015). Public debt and growth: Heterogeneity and non-linearity. Journal of International Economics, 97, 45-58. https://doi.org/10.1016/j.jinteco.2015.04.005

EC Europa. (2019). Retrieved November 25, 2019, from https://ec.europa.eu/commission/presscorner/detail/ en/MEMO_19_2815

EUR-Lex. (2019). Retrieved November 25, 2019, from https://eur-lex.europa.eu/legal-content/EN/ALL/?uri= CELEX:31997Y0802(01)

Eurostat. (2019). General government gross debt - annual data. Retrieved November 15, 2019, from https:/ec.europa.eu/eurostat/tgm/download.do?tab=table\&plugin=1\&language=en $\&$ pcode=teina225 
Fincke, B., \& Greiner, A. (2015). Public Debt and Economic Growth in Emerging Market Economies. South African Journal of Economics, 83(3), 357-370. Retrieved November 30, 2019, from https://doi.org/10.1111/saje.12079

Forte, F., \& Magazzino, C. (2016). Fiscal policies in EMU countries: Strategies and empirical evidence. Journal of International Trade Law and Policy, 15(1). https://doi.org/10.1108/JITLP-10-2015-0031

Gil, J., \& de Souza, L. V. (2013). The Flight of the European Bumblebee. Project Syndicate.

Henning, C. R., \& Kessler, M. (2012) Fiscal Federalism: U.S. History for Architects of Europe's Fiscal Union. Peterson Institute for International Economics Working paper 12-1 (January). Retrieved November 25, 2019, from https://www.piie.com/sites/default/files/publications/wp/wp12-1.pdf

Herndon, T., Ash, M., \& Pollin, R. (2013). Does High Public Debt Consistently Stifle Economic Growth? A Critique of Reinhart and Rogoff. Political Economy Research Institute Working Paper Series Number 322. Retrieved December 1, 2019, from http://www.peri.umass.edu/fileadmin/pdf/working_papers/working_papers_301-350/WP322.pdf

Kenen, P. (1969). The Optimum Currency Area: An Eclectic View Mundell \& Swoboda eds. Chicago. University of Chicago Press

Kinsella, S. (2012). Is Ireland really the role model for austerity? Cambridge Journal of Economics, 36(1), 223-235. https://doi.org/10.1093/cje/ber032

Kurecic, P., Kokotovic, F., \& Bandov, G. (2018). A Review of the Rise of the US Public Debt Limit: Selected Theoretical Contributions and Legislative Changes. Journal of Economic and Social Development, 5(2), 30. Retrieved November 15, 2019, from https://bib.irb.hr/datoteka/956220.EBOOK_Journal_CJ02_ART_4.pdf

Liapis, K., Rovolis, A., \& Galanos, C. (2013). Toward a Common Tax Regime for the European Union Countries. European Research Studies, 16(3), 93. Retrieved November 25, 2019, from https://search.proquest.com/openview/d5c70fa8c178a34a68b7fe844d0ce946/1?pq-origsite $=$ gscholar\&cbl=6 0370

Liu, H. C., \& Wang, H. B. (2013). The Effect of Eurozone Crisis on Eurozone ADR Pricing. Journal of International Business Research, 12(1), 79. Retrieved November 26, 2019, from https://www.abacademies.org/articles/jibrvol12no12013.pdf\#page $=85$

Magazzino, C., \& Lepore, F. (2015). Le politiche di bilancio nell Eurozona: Strategie ed evidenza empirica. Rivista Bancaria--Minerva Bancaria, 5-6, 103-142. Retrieved November 27, 2019, from https://papers.ssrn.com/sol3/papers.cfm?abstract_id=2692472

Maloney, J., \& Macmillen, M. (1999). Do Currency Unions Grow Too Large for Their Own Good? The Economic Journal, 109(458), 572-587. https://doi.org/10.1111/1468-0297.00463

Martin, F. M., \& Waller, C. J. (2012). Sovereign Debt: A Modern Greek Tragedy. Federal Reserve Bank of St. Louis Review, 94(5), 321. https://doi.org/10.20955/r.94.321-340

Mencinger, J., Verbic, M., \& Aristovnik, A. (2015). Revisiting the role of public debt in economic growth: The case of OECD countries. Engineering Economics, 26(1), 61-66. https://doi.org/10.5755/j01.ee.26.1.4551

Merler, S., \& Pisani-Ferry, J. (2012). Sudden Stops in the Euro Area. Bruegel Policy Contribution (March). https://doi.org/10.5202/rei.v3i3.97

Mundell, R. A. (1961). A Theory of Optimal Currency Areas. The American Economic Review, 51(4), 657-665. Retrieved November 23, 2019, from https://www.jstor.org/stable/1812792

OECD Edu. (2019). Population with tertiary education. Retrieved November 25, 2019, from https://data.oecd.org/eduatt/population-with-tertiary-education.htm

OECD Tax. (2019). Statutory corporate income tax rate. Retrieved November 25, 2019, from https://stats.oecd.org/Index.aspx?QueryId=78166

OEC World. (2019). Selection of Countries. Retrieved November 25, 2019, from https://oec.world/en/

Panizza, U., \& Presbitero, A. F. (2014). Public debt and economic growth: Is there a causal effect? Journal of Macroeconomics, 41, 21-41. https://doi.org/10.1016/j.jmacro.2014.03.009

Parkin, M. (2012). Macroeconomics (10th ed.). Pearson.

Pureza, J. M., \& Mortagua, M. (2016). The European Neoliberal Order and the Eurocrisis: Blame It All on 
$\begin{array}{lllll}\text { Germany? } \quad \text { World } & \text { Review }\end{array}$ https://doi.org/10.13169/worlrevipoliecon.7.3.0363

Reinhart, C. M., \& Rogoff, K. S. (2010). Debt and growth revisited. MPRA Paper 24376. University Library of Munich, Germany. 34. Retrieved November 30, 2019, from https://voxeu.org/article/debt-and-growth-revisited

Saunders, D. C. (2011). Stability of the European Optimum Currency Area. Indian Journal of Economics and Business, 10(4), 425. Retrieved November 1, 2019, from https://www.questia.com/library/journal/1G1-278509626/stability-of-the-european-optimum-currency-area

Silvia, S. J. (2004). Is the Euro Working? The Euro and European Labour Markets. Journal of Public Policy, 24(2), 147-168. https://doi.org/10.1017/S0143814X0400008X

Tanner, M. (2013). Introduction: Europe's Crisis and the Welfare State. The Cato Journal, 33(2), 187. Retrieved November 28, 2019, from https://heinonline.org/HOL/LandingPage?handle=hein.journals/catoj33\&div=15

Teica, R. A. (2012). Analysis of the public debt sustainability in the economic and monetary union. Procedia Economics and Finance, 3, 1081-1087. https://doi.org/10.1016/S2212-5671(12)00277-8

Vanhorebeek, F., \& Van Rompuy, P. (1995). Solvency and sustainability of fiscal policies in the EU. De Economist, 143(4), 457-473. https://doi.org/10.1007/BF01384910

World Bank. (2019). The World Bank Data Bank World Development Indicators. Retrieved August 1, 2019, from https://databank.worldbank.org/data/reports.aspx?source=world-development-indicators\#?

\section{Appendix}

\begin{tabular}{|c|c|c|c|c|c|c|}
\hline Table 1. & 2013 & 2018 & 2013 & 2018 & 2013 & 2018 \\
\hline Portugal, Ireland, Italy Measurements & Portugal & Portugal & Ireland & Ireland & Italy & Italy \\
\hline \multicolumn{7}{|l|}{ Trade Flows } \\
\hline \multirow[t]{2}{*}{ Trade (\% of GDP) } & 78.03 & 87.02 & 188.25 & 209.81 & 55.47 & 61.01 \\
\hline & & $12 \%$ & & $11 \%$ & & $10 \%$ \\
\hline \multirow[t]{2}{*}{ Exports of goods and services (\% of GDP) } & 39.52 & 43.59 & 103.51 & 120.52 & 28.86 & 31.76 \\
\hline & & $10 \%$ & & $16 \%$ & & $10 \%$ \\
\hline \multirow[t]{2}{*}{ External trade balance (\% of GDP) } & 1.01 & 0.15 & 18.78 & 31.23 & 2.26 & 2.50 \\
\hline & & $-85 \%$ & & $66 \%$ & & $11 \%$ \\
\hline \multicolumn{7}{|l|}{ Industry / Debt / FDI } \\
\hline \multirow[t]{2}{*}{ Industry (including construction), value added (\% of GDP) } & 18.88 & 19.51 & 24.31 & 35.42 & 21.33 & 21.65 \\
\hline & & $3 \%$ & & $46 \%$ & & $2 \%$ \\
\hline \multirow[t]{2}{*}{ General government gross debt (\% of GDP), least ranked } & 129.00 & 121.50 & 119.70 & 64.80 & 129.00 & 132.20 \\
\hline & & $-6 \%$ & & $-46 \%$ & & $2 \%$ \\
\hline \multirow[t]{2}{*}{ FDI net inflows ( $\%$ of GDP) } & 4.78 & 2.04 & 20.91 & 5.68 & 0.92 & 1.49 \\
\hline & & $-57 \%$ & & $-73 \%$ & & $63 \%$ \\
\hline \multicolumn{7}{|l|}{ Demographics } \\
\hline \multirow[t]{2}{*}{ Population growth (annual \%) } & $(0.55)$ & $(0.18)$ & 0.53 & 0.95 & 1.16 & $(0.17)$ \\
\hline & & $67 \%$ & & $81 \%$ & & $-115 \%$ \\
\hline \multirow[t]{2}{*}{ Age dependency ratio, old ( $\%$ of workers), least ranked $*$} & 30.26 & 33.83 & 18.65 & 22.24 & 33.43 & 36.86 \\
\hline & & $12 \%$ & & $19 \%$ & & $10 \%$ \\
\hline \multirow[t]{2}{*}{ Unemployment, total ( $\%$ of total labor force), least ranked } & 16.18 & 6.86 & 13.74 & 5.69 & 12.15 & 10.20 \\
\hline & & $-58 \%$ & & $-59 \%$ & & $-16 \%$ \\
\hline
\end{tabular}




\begin{tabular}{|c|c|c|c|c|c|c|}
\hline \multicolumn{7}{|l|}{ Economic Outcomes } \\
\hline \multirow[t]{2}{*}{ Inflation, GDP deflator (annual \%) } & 2.27 & 1.42 & 1.33 & 1.52 & 1.21 & 0.85 \\
\hline & & $-37 \%$ & & $14 \%$ & & $-30 \%$ \\
\hline \multirow[t]{2}{*}{ Current account balance ( $\%$ of GDP) } & 1.59 & $(0.63)$ & 6.04 & 9.21 & 1.00 & 2.44 \\
\hline & & $-140 \%$ & & $52 \%$ & & $144 \%$ \\
\hline \multirow[t]{2}{*}{ GDP per capita (current USD) } & 21,619 & 23,146 & 51,590 & 78,806 & 35,370 & 34,318 \\
\hline & & $7 \%$ & & $53 \%$ & & $-3 \%$ \\
\hline
\end{tabular}

$*=$ the ratio of older dependents, people older than 64 , to the working-age population, those ages $15-64$

\begin{tabular}{|c|c|c|c|c|c|c|}
\hline Table 2. & 2013 & 2018 & 2013 & 2018 & 2013 & 2018 \\
\hline Greece, Spain, EU Measurements & Greece & Greece & Spain & Spain & EU & EU \\
\hline \multicolumn{7}{|l|}{ Trade Flows } \\
\hline \multirow[t]{2}{*}{ Trade (\% of GDP) } & 63.52 & 72.52 & 61.18 & 66.60 & 81.93 & 86.49 \\
\hline & & $14 \%$ & & $9 \%$ & & $6 \%$ \\
\hline \multirow[t]{2}{*}{ Exports of goods and services (\% of GDP) } & 30.35 & 36.13 & 32.22 & 34.28 & 42.31 & 44.74 \\
\hline & & $19 \%$ & & $6 \%$ & & $6 \%$ \\
\hline \multirow{2}{*}{ External trade balance (\% of GDP) } & $(2.81)$ & $(0.26)$ & 3.26 & 1.95 & 2.68 & 2.99 \\
\hline & & $91 \%$ & & $-40 \%$ & & $12 \%$ \\
\hline \multicolumn{7}{|l|}{ Industry / Debt / FDI } \\
\hline \multirow[t]{2}{*}{ Industry (including construction), value added (\% of GDP) } & 14.66 & 15.27 & 21.24 & 21.91 & 21.90 & 21.87 \\
\hline & & $4 \%$ & & $3 \%$ & & $0 \%$ \\
\hline \multirow[t]{2}{*}{ General government gross debt (\% of GDP), least ranked } & 177.40 & 181.10 & 95.50 & 97.10 & 85.80 & 80.00 \\
\hline & & $2 \%$ & & $2 \%$ & & $-7 \%$ \\
\hline \multirow[t]{2}{*}{ FDI net inflows ( $\%$ of GDP) } & 1.23 & 1.98 & 3.84 & 3.18 & 3.41 & 0.49 \\
\hline & & $61 \%$ & & $-17 \%$ & & $-86 \%$ \\
\hline \multicolumn{7}{|l|}{ Demographics } \\
\hline \multirow[t]{2}{*}{ Population growth (annual \%) } & $(0.73)$ & $(0.25)$ & $(0.33)$ & 0.28 & 0.30 & 0.20 \\
\hline & & $65 \%$ & & $185 \%$ & & $-33 \%$ \\
\hline \multirow[t]{2}{*}{ Age dependency ratio, old ( $\%$ of workers), least ranked $*$} & 29.16 & 31.54 & 27.13 & 30.00 & 27.94 & 31.09 \\
\hline & & $8 \%$ & & $11 \%$ & & $11 \%$ \\
\hline \multirow[t]{2}{*}{ Unemployment, total ( $\%$ of total labor force), least ranked } & 27.47 & 19.21 & 26.09 & 15.49 & 10.82 & 6.82 \\
\hline & & $-30 \%$ & & $-41 \%$ & & $-37 \%$ \\
\hline \multicolumn{7}{|l|}{ Economic Outcomes } \\
\hline \multirow[t]{2}{*}{ Inflation, GDP deflator (annual \%) } & $(2.35)$ & 0.55 & 0.35 & 0.99 & 1.31 & 1.92 \\
\hline & & $123 \%$ & & $179 \%$ & & $47 \%$ \\
\hline \multirow[t]{2}{*}{ Current account balance (\% of GDP) } & $(2.06)$ & $(2.92)$ & 1.52 & 0.91 & - & - \\
\hline & & $-42 \%$ & & $-41 \%$ & & $0 \%$ \\
\hline \multirow[t]{2}{*}{ GDP per capita (current USD) } & 21,875 & 20,324 & 29,212 & 30,524 & 35,635 & 36,546 \\
\hline & & $-7 \%$ & & $4 \%$ & & $3 \%$ \\
\hline
\end{tabular}

$*=$ the ratio of older dependents, people older than 64 , to the working-age population, those ages $15-64$ 


\begin{tabular}{llllllll}
\hline Table 3. & 2018 & 2018 & 2018 & 2018 & 2018 & 2018 \\
\hline PIIGS, EU:2018 Measurements & Portugal & Ireland & Italy & Greece & Spain & EU \\
\hline
\end{tabular}

Trade Flows

Trade $(\%$ of GDP)

Exports of goods and services (\% of GDP)

External trade balance (\% of GDP)

Industry / Debt / FDI

Industry (including construction), value added (\% of GDP)

General government gross debt (\% of GDP), least ranked

FDI net inflows (\% of GDP)

Demographics

Population growth (annual \%)

Age dependency ratio, old (\% of workers), least ranked *

Unemployment, total (\% of total labor force), least ranked

33.83

6.86

1.42

(0.63)

23,146

19.51

121.50

\section{Economic Outcomes}

Inflation, GDP deflator (annual \%)

Current account balance ( $\%$ of GDP)

GDP per capita (current USD)
209.81

61.

31.76

120.52

31.23

2.50

$(0.26)$

1.95

86.49

44.74

2.99

35.42

21.65

15.27

21.91

21.87

64.80

132.20

181.1

97.10

80.00

5.68

1.49

1.98

3.18

0.49

$\begin{array}{lllll}0.95 & (0.17) & (0.25) & 0.28 & 0.20 \\ 22.24 & 36.86 & 31.54 & 30.00 & 31.09 \\ 5.69 & 10.20 & 19.21 & 15.49 & 6.82\end{array}$

(6.82

$$
10.20
$$

19.21

$*=$ the ratio of older dependents, people older than 64 , to the working-age population, those ages $15-64$

\begin{tabular}{lllllll}
\hline Table 4. & 2018 & 2018 & 2018 & 2018 & 2018 & 2018 \\
\hline PIIGS, EU:2018 Rankings & Portugal & Ireland & Italy & Greece & Spain & EU \\
\hline
\end{tabular}

Trade Flows

Trade (\% of GDP)

Exports of goods and services (\% of GDP)

External trade balance (\% of GDP)

$\begin{array}{llllll}2 & 1 & 6 & 4 & 5 & 3 \\ 3 & 1 & 6 & 4 & 5 & 2 \\ 5 & 1 & 3 & 6 & 4 & 2\end{array}$

Industry / Debt / FDI

Industry (including construction), value added (\% of GDP) 5

General government gross debt (\% of GDP), least ranked 4

FDI net inflows (\% of GDP)

Demographics

Population growth (annual \%)

Age dependency ratio, old (\% of workers), least ranked * 5

Unemployment, total ( $\%$ of total labor force), least ranked 3

\begin{tabular}{llllll}
5 & 1 & 4 & 6 & 2 & 3 \\
5 & 1 & 6 & 4 & 2 & 3 \\
3 & 1 & 4 & 6 & 5 & 2 \\
\hline
\end{tabular}


Economic Outcomes

Inflation, GDP deflator (annual \%)

Current account balance ( $\%$ of GDP)

GDP per capita (current USD)

$\begin{array}{llllll}3 & 2 & 5 & 6 & 4 & 1 \\ 5 & 1 & 2 & 6 & 3 & 4 \\ 5 & 1 & 3 & 6 & 4 & 2\end{array}$

Section Ranking

Trade Flows

Industry / Debt / FDI

3

4

Demographics

Economic Outcomes

Overall Ranking

4

5

4

$\begin{array}{lllll}1 & 6 & 4 & 4 & 2 \\ 1 & 5 & 6 & 2 & 3 \\ 1 & 5 & 6 & 3 & 2 \\ 1 & 3 & 6 & 4 & 2\end{array}$

$*=$ the ratio of older dependents, people older than 64 , to the working-age population, those ages $15-64$

\section{Copyrights}

Copyright for this article is retained by the author(s), with first publication rights granted to the journal.

This is an open-access article distributed under the terms and conditions of the Creative Commons Attribution license (http://creativecommons.org/licenses/by/4.0/). 